\title{
THE DIVERSITY OF HERBACEOUS VEGETATION AFTER FOREST FIRE
}

Jolita ABRAITIENE், Institute of Forest Biology and Silviculture, Faculty of Forestry and Ecology, Aleksandras Stulginskis University, Studentu str. 11, LT-53361 Academy, Kaunas distr., Lithuania, jolita.abraitiene@ asu.lt

Gerda ŠILINGIENĖ, Institute of Forest Biology and Silviculture, Faculty of Forestry and Ecology, Aleksandras Stulginskis University, Studentu str. 11, LT-53361 Academy, Kaunas distr. Lithuania, gerda.silingiene@ asu.lt (corresponding author)

Rasa VAITKEVIČIŪTÉ, Institute of Forest Biology and Silviculture, Faculty of Forestry and Ecology, Aleksandras Stulginskis University Studentu str. 11, LT-53361 Academy, Kaunas distr. Lithuania, rasa.vaitkeviciute@ asu.lt

Regina VASINAUSKIENE, Institute of Forest Biology and Silviculture, Faculty of Forestry and Ecology, Aleksandras Stulginskis University Studentu str. 11, LT-53361 Academy, Kaunas distr. Lithuania, regina.vasinauskiene@ asu.lt

Forest fire is an uncontrolled combustion of flammable materials in forested and non-forested areas. In Lithuania forest fires mainly occur in late spring and summer, mostly in young coniferous forests (Forest ..., 1987).

The studies of herbaceous plants in fireplaces were carried out in 2016 in Jurbarkas SFE. Ground-level forest fire increased the projection coverage of herbaceous plants and their species composition in the fireplaces. According to the average data of the survey, 18 herbaceous plant species were ascertained in the fireplace and 14 species in the control stand. During the first year after fire, 9 new species were recorded in the fireplace and 5 species have disappeared, while in the seventh year - 7 new species were recorded and 1 disappeared, as compared with the control stand. Summarizing the obtained data it can be stated that low-intensity ground-level forest fire in pine forest increased the number of herbaceous plant species, however, the number of new and extinct species has been gradually decreasing, suggesting that in the fireplaces the diversity of herbaceous plant species will be like in the control stand.

Keywords: Forest fire, herbaceous plants, projection coverage

\section{INTRODUCTION}

Forest is an invaluable asset with many important functions: it maintains ecological sustainability in the country, accumulates $\mathrm{CO}_{2}$, and at the same time stops the growth of carbon in the atmosphere. The forest suffers from biotic, abiotic and anthropogenic factors every year. Forest fire is the most dangerous abiotic factor which changes the forest ecosystem (Kuuluvainen, 2002).

Forest fire is an uncontrolled combustion in forested or unoccupied by forest areas (Marozas, 2008). In Lithuania and in many parts of the world (eg Canada, Australia) fires are divided into three main types: underground, surface and crown fires. Of these, the most dangerous are crown fires and intensive fires of the other types (Ozolinčius, 2005; Račinskas, 2007; Venckus, 2010). Surface forest fires occur the most frequently in Lithuania (97\%), much less frequent are underground (2\%) and crown (1\%) fires (Ozolinčius, 2005).

The rise and spread of fire depends on the sanitary condition of the forest, preventive measures, meteorological conditions and anthropogenic factors (Grigaliūnas, 2002). Factors such as the distance to the traffic roads and cities also strongly influence the rise of fires. The increase in the number of fires is also related to an increase in the number of inhabitants, as tourism and recreation are expanding along with the population. In rarer cases fires occur due to natural factors such as lightning (Ganteaume et al., 2012; Račinskas, 2007; Daraškevičius et al., 1967). The likelihood of a fire depends on the characteristics of the stands: habitat, species composition, stocking level, age, and so on (Granström, 1993).

One of the most important factors in the development of fires is the habitat. Fires usually occur in dry lowyielding habitats, and especially favourable conditions occur when peatland forests are drained. In fertile habitats grow more resistant to fire tree species, mostly deciduous or mixed stands, with a second storey of trees, understorey or herbaceous cover (Račinskas and Marozas, 2005).

Fire hazard depends mostly on the effectiveness of fire-prevention measures. Fire protection of forests in accordance with the Forest Fire Protection Rules must be taken care of by all forest managers. Fighting against forest fires can be of several types: warning (information tools, fire propaganda, etc.), fire protection (fire barriers, observation towers, etc.) and direct ones - fire fighting (Forest Fire Protection Rules, 2015; Venckus, 2010).

The consequences of forest fires can be negative and positive. The consequences of the fire depend on the intensity of a forest fire. After intense fires, there are economic losses. Due to intense fires, in a short period of time distribution, and reproduction in any medium, provided the original author and source are credited. 
stands are damaged or completely destroyed, and at the same time the structure of soil, fauna and flora are altered. After heavy fires, forest components recover only over a long period of time. Many studies have shown that after surface fires the species composition of the vegetation increases (Cook 2008; Kuuluvainen, 2002; Marozas et al., 2013; Marozas et al., Marozas 2008; 2011; Ozolinčius 1998; Račinskas, 2007).

The consequences of a fire depend on its intensity, so minor fires can be useful. Fires of low intensity reduce the risk of pest outbreak formation, and the spread of diseases. One of the most prominent indicators proving the positive side of fires is biodiversity, which is poor in the first year after fire, but then begins to increase significantly (Jakas, et al. 2009). Increasingly, controlled fires are applied, which are not only beneficial for many of the mentioned factors, but also for research, and the reduction of the effects of bigger fires (Kuuluvainen, 2002, Granström, 1993). After evaluating both the positive and the negative effects of fires, the concept of "fighting forest fires" is also mitigate $\mathrm{d}$ by changing it to the term "forest fire management" (FAO, 2006).

The issue of fire hazard is relevant to every forest owner and forester who cares about the forest. It is important to properly evaluate the risk of fire and the consequences after it not only from the economic, but also from the ecological viewpoint. In order to evaluate the impact of fires on the forest, it is important to evaluate the longest possible time span after the fire.

The aim of the study is to determine the change of herbaceous vegetation after the surface fire.

\section{OBJECT AND METHODS}

The object of the research is the forests of the Jurbarkas State Forest Enterprise (Fig. 1). The SFE is located in the territory of the Jurbarkas District Municipality, which is an administrative unit in the southwestern part of Lithuania. The forests are located on the right bank of the river Nemunas.

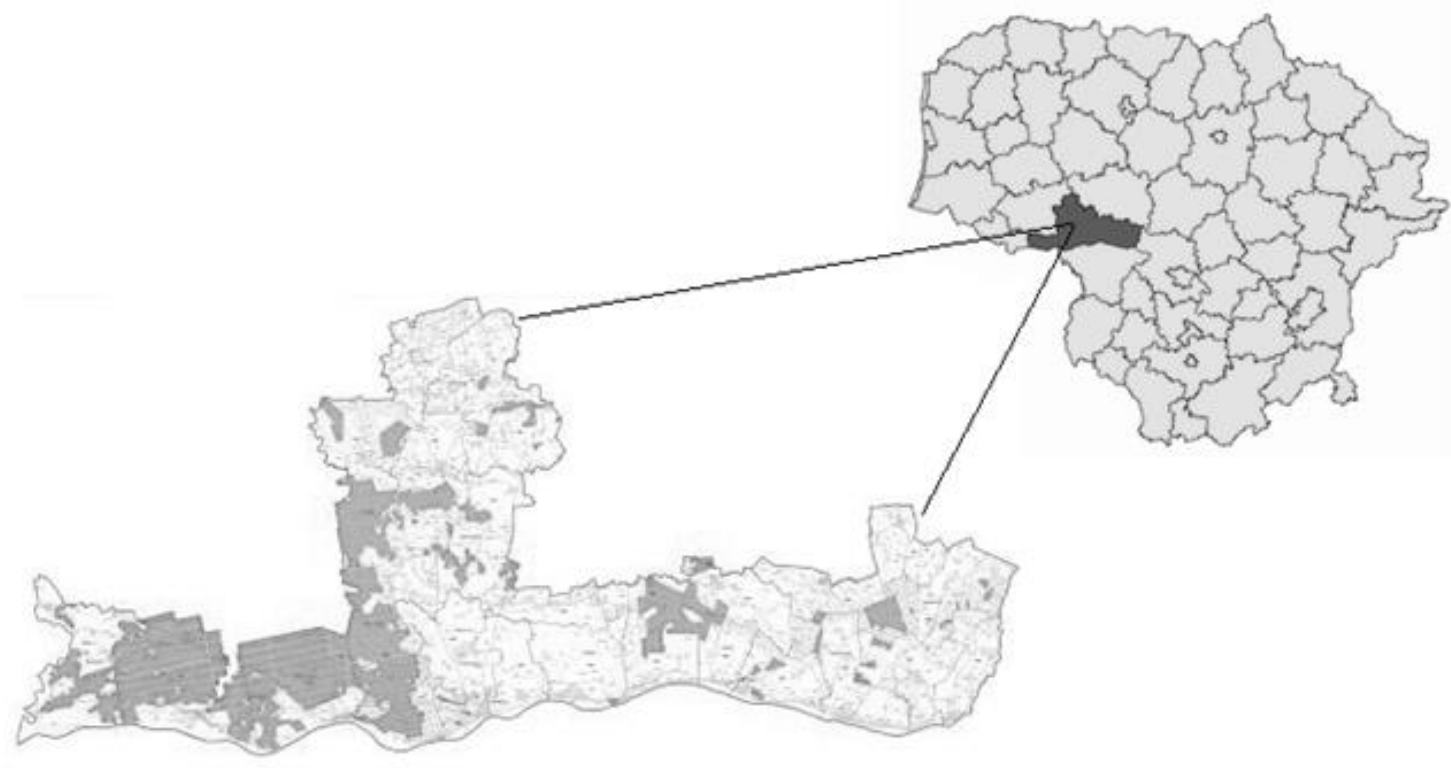

Figure 1. Research object - the forests of Jurbarkas State Forest Enterprise

The largest part of the territory of the SFE consists of young stands and middle-aged stands (young stands - 29\%, middle-aged $-39 \%$, under mature $-13 \%$, mature $-19 \%$ ). According to stand inventory data, it was found that in the territory of the SFE there are a lot of forests in which the conditions for fires are particularly favourable. The forests of high natural flammability classes occupy $34 \%$, those of average $-19 \%$, and forests of low flammability $-47 \%$.

Investigations of herbaceous vegetation at fire sites were carried out in August 2016 in the territory of Jurbarkas Forest Enterprise (Pašventis forest distr., block 30, stocking 5;9; Mociškes forest distr., block 71, stocking 7;9, Jūrava forest distr., block 4, stocking 5; Smalininkai forest distr., block 76, stocking 11). For the study, pine forests (site $\mathrm{Nb}$ of normal humidity (N) on infertile soil (b)), which had moderate surface fires in 2015, 2014, 2013 and 2009 were selected.

For herbaceous vegetation studies, 1x1 m sample plots have been identified, in which the number of herbaceous plant species and the percentage of projection coverage were estimated. Plots of the same size were identified in stands nearby fireplaces for the control data.

For data analysis, the Microsoft Excel program was applied.

\section{RESULTS}

In the pine stand after surface forest fire on $\mathrm{Nb}$ site species composition of herbaceous vegetation increased by about $30 \%$ than in the control (Fig. 2). On average, $18 \pm 1.1$ species of herbaceous plants were found in fire sites, and $14 \pm 0.7$ in the control stands. After surface forest fire, most new species were inventoried in the seventh year after fire, while the least number was inventoried in the third year, respectively by $50 \%$ and $23 \%$ more than in the control. 
According to the average survey data, $8 \pm 0.4$ new species of herbaceous plants were inventoried at fire sites, while 4 \pm 1.2 species of herbaceous plants disappeared, as compared to the control stands.

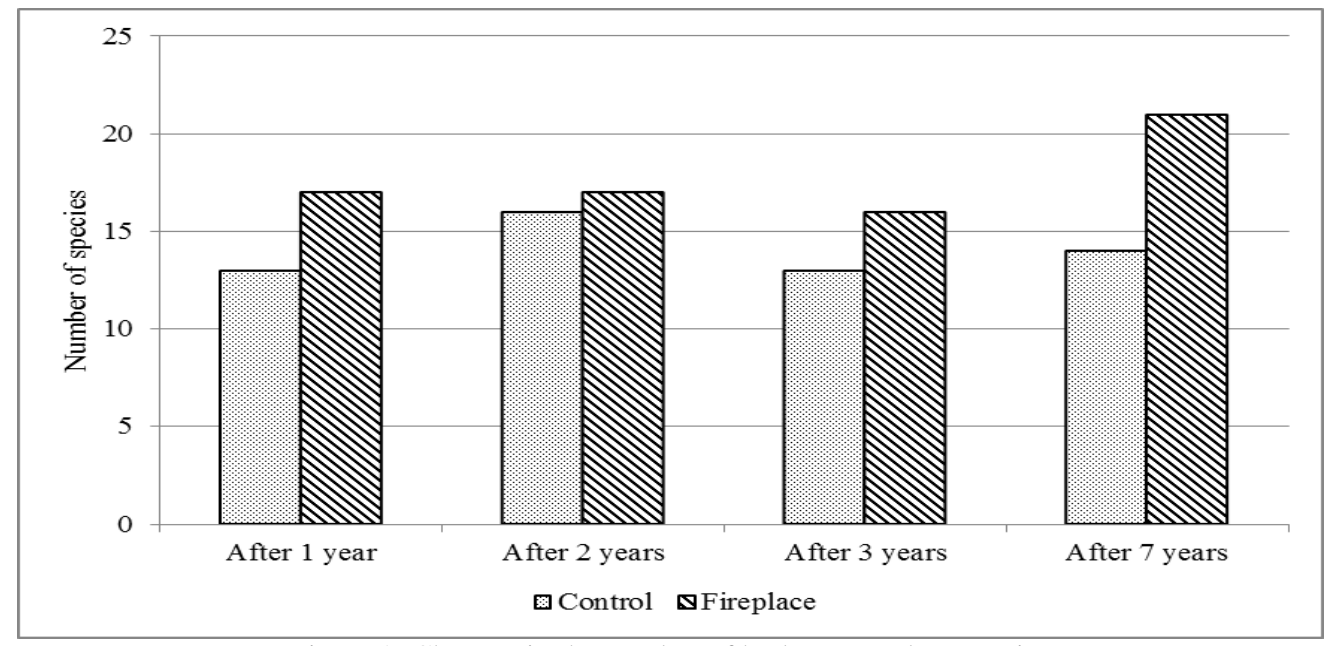

Figure 2. Changes in the number of herbaceous plant species

The analysis of the data showed that there were 9 families of herbaceous plants in the control stands, and 11 families in the fire sites (Fig. 3). The most abundant in fire sites after 1 year were the grass family (Poaceae (Gramineae) (R. Br.) Bernhart), ericaceous plants (Ericaceae Juss.), the aster family (Asteraceae Dumort. (Compositae G.)), after 2 years - the aster family (Asteraceae Dumort. (Compositae G.)), in the 3rd year - the grass family (Poaceae (Gramineae) (R. Br.) Bernhart), ericaceous (Ericaceae Juss.), and in the 7th year - the rose family (Rosaceae Juss .), the grass family (Poaceae (Gramineae) (R. Br.) Bernhart), ericaceous plants (Ericaceae Juss.) and the lily of the valley family (Convallariaceae Horan.). After 1-3 years following the fire, there were found representatives of the carrot (Peucedanum oreoselinum (L.) Moench), and horsetail (Equisetum heymale L.) families, which were not found at the fire site after 7 years since the fire.

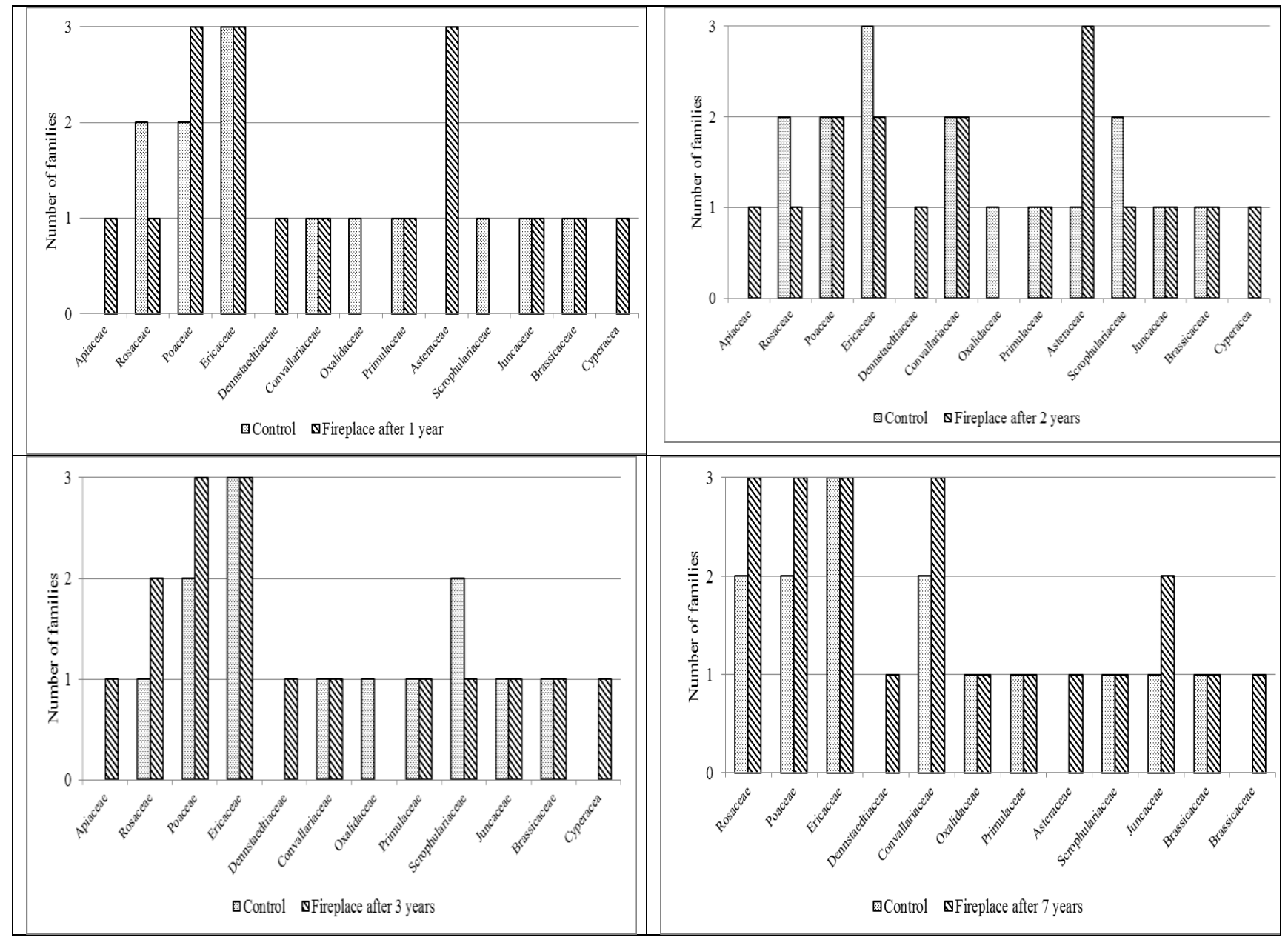

Figure 3. The number of herbaceous plant families 
The projection coverage of herbaceous plants at fire sites varied depending on the age of the fire site. In the first year after fire, the average projection coverage of herbaceous plants was $3.7 \pm 0.5$ per cent, in the second $-6.5 \pm 0.9$ per cent, in the third $-9.0 \pm 1.3$ per cent, and in the seventh $-8.5 \pm 1.4$ per cent. To sum up, it can be stated that the projection coverage of herbaceous plants in fire sites decreased (twice lower than in the control) in the first year after fire, while in the third year it equalled the control.

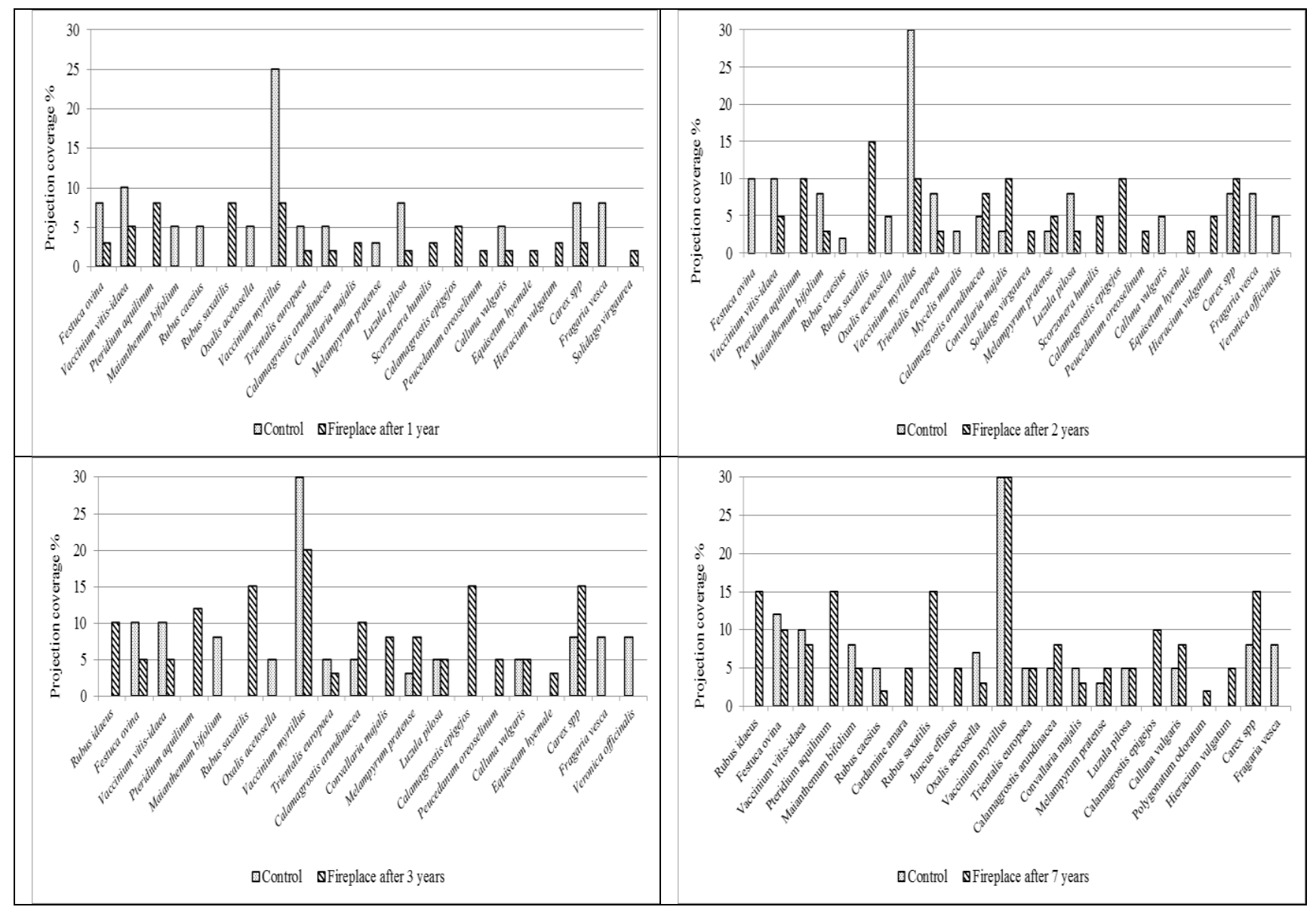

Figure 4. Projection coverage of herbaceous plants

After surface forest fire began to grow eagle fern (Pteridium aquilinum (L.) Kuhn), stone bramble (Rubus saxatilis L.), bushgrass (Calamagrostis epigejos (L.) Roth), mountain parsley (Peucedanum oreoselinum (L.) Moench), rough horsetail (Equisetum hyemale L.), and common hawkweed (Hieracium aggr. vulgatum Fr.), while in the control stands they were not identified. The most abundantly these plants grew in the seventh year after fire. The greatest projection coverage was that of the eagle fern (Pteridium aquilinum (L.) Kuhn), stone bramble (Rubus saxatilis L.), while the smallest was that of common hawkweed (Hieracium aggr. vulgatum Fr.), respectively $15 \%$ and $5 \%$.

\section{CONCLUSIONS}

Forest fires have had an impact on herbaceous vegetation. After forest fire increased the number of families (by 2 families) and the number of species (by 8 species) in the fire sites. The biggest change in the diversity of herbaceous plants was observed 3 years after fire, when a characteristic species emerged in the fire sites - the eagle fern. A low intensity forest fire in pine forest has increased the number of herbaceous plants, but the number of new and extinct species was gradually decreasing, thus it can be assumed that the diversity of herbaceous plants in the fire sites will be the same as in the control stands.

According to the average data of the study, in the control stands there were 9 families of herbaceous plants and the projection coverage was $8.0 \pm 0.8 \%$, respectively in the fire sites there were 11 families and the projection coverage was $7.0 \pm 0.6 \%$. The most abundant families in the fire sites were those of grasses (Poaceae (Gramineae) (R. Br.) Bernhart) and ericaceous plants (Ericaceae Juss.).

\section{REFERENCES}

1. Cook, J. E., Jensen, N., Galbraith, B. 2008. Composition, cover and diversity changes after prescribed fire in a nature eastern pine forest. Botany, Vol. 86, No. 12, pp. 1427-1439. https://doi.org/10.1139/B08-111

2. Daraškevičius, V., Džiaukštas, P., Navasaitis, A., Repšys, J., Žadeikis, R. 1967. Miškininkystė. Vilnius: Mintis, p.. 209 -213. [In Lithuanian] 


\section{Proceedings of the $8^{\text {th }}$ International Scientific Conference Rural Development 2017}

3. Dèl miškų priešgaisrinès apsaugos taisyklių patvirtinimo [interaktyvus]/ Lietuvos Respublikos ministro ir Lietuvos Respublikos miško ūkio ministro įsakymas: 199504 07, Nr. 500. Suvestinè redakcija nuo 201503 10. . [In Lithuanian]

4. FAO. 2006 Fire management: voluntary guidelines. Principles and strategic actions. Fire management. Working paper, Vol. 17. Rome, 61.

5. Ganteaume, A., Camia, A., Jappiot, M., San-Miguel- Ayanz, J., Long-Fournel, M., Lampin, C. 2012. A Review of the Main Driving Factors of Forest Fire Ignition Over Europe.

6. Granström, A. 1993. Spatial and temporal variation of lightning ignitions in Sweden. Journal of Vegetation Science, Vol. 4, pp. 737-744. https://doi.org/10.2307/3235609

7. Grigaliūnas J. 2002. Mūsų miškas (Our forest). Kaunas: Spindulys. pp. 107-111 . . [In Lithuanian]

8. Jakas, P., Račinskas, J., Marozas V. 2009. Mišku priešgaisrinė apsauga. Akademija. P. 63-64. . [In Lithuanian]

9. Kuuluvainen, T., 2002. Natural variability of forests as a reference for restoring and managing biological diversity in boreal Fennoscandia. Silva Fenn, Vol. 36(1), pp. 97-125. https://doi.org/10.14214/sf.552

10. Marozas, V. 2008. Pažeminių gaisrų ịtaka pušynų augmenijos įvairovei ir savaiminiam žèlimui stebėsena: mokslinio tiriamojo darbo ataskaita, pp. 5-28. [In Lithuanian]

11. Marozas, V., Armolaitis, K., Aleinikoviené, J. 2013. Changes of ground vegetation, soil chemical properties and microbiota following the surface fires in Scots pine forests. Journal of environmental engineering and landscape management, Vol. 21, No. 1, pp. 67-75.

12. Marozas, V., Plaušinytė, E., Augustaitis, A., Kačiulytè, A. 2011. Changes of ground vegetation and tree-ring growth after surface fires in scots pine forests. Acta biologica universitatis Daugavpiliensis, Vol. 11, No.2, pp. 156-162.

13. Ozolinčius, R. 2005. Miškų gaisrai ir jų prevencijos. P.18. [In Lithuanian]

14. Ozolinčius, R. 1998. Miškų gaisrai. Mūsų girios. No. 6(602), pp. 10-11. [In Lithuanian]

15. Račinskas, J. 2007. Miško gaisrų gesinimas. Baltijos miškai ir mediena. No. 07, pp. 60-64. [In Lithuanian]

16. Račinskas, J., Marozas, V. 2005. Pažeminių gaisrų ịtaka pušynų fitocenozès komponentams. Miškininkystè, No. 2 (58), pp. 63-74. [In Lithuanian]

17. Venckus, Z. 2010. Miškų naudojimas, atkūrimas, apsauga: mokomoji knyga. Šiaulių universitetas, gamtos mokslų fakultetas: Vši Šiaulių universiteto leidykla, pp. 130-133. [In Lithuanian] 